\title{
The Faculty Jurisdiction Rules 2013: Simpler Process, Equal Protection
}

\section{MARK HILL QC}

\author{
Chancellor of the Diocese of Chichester \\ Honorary Professor, Centre for Law and Religion, Cardiff University \\ Extraordinary Professor, Department of Church Polity, University of Pretoria
}

\begin{abstract}
The faculty jurisdiction of the Church of England pre-dates planning law by several centuries. It is the means by which the diocesan bishop, through his chancellor and in his consistory court, ensures that the sacred buildings of the diocese and their contents are compliant with the canon law, doctrine and ecclesiology of the Church of England. During the latter part of the last century, the effective operation of the faculty jurisdiction contributed to the continuing exclusion of churches of the Church of England from the need for listed building control. The rationale is that the faculty jurisdiction provides a level of protection for the church's built heritage equivalent to local authority protection, but uniquely tailored for the sacred purpose of the buildings and the evolving needs of individual worshipping communities. A balance constantly needs to be struck which respects the rigour required of both ecclesiastical and secular authorities (with their competing but complementary demands), but is not so cumbersome that it deters and frustrates parishes and other interested persons and bodies from engaging with it.
\end{abstract}

Keywords: faculty jurisdiction, procedure, 2013 Rules

The faculty jurisdiction of the Church of England pre-dates planning law by several centuries. It is the means by which the diocesan bishop, through his chancellor and in his consistory court, ensures that the sacred buildings of the diocese and their contents are compliant with the canon law, doctrine and ecclesiology of the Church of England. ${ }^{1}$ During the latter part of the last century, the effective operation of the faculty jurisdiction contributed to the continuing exclusion of churches of the Church of England from the need for listed building control. The rationale is that the faculty jurisdiction provides a level of protection for the church's built heritage equivalent to local authority protection, but uniquely tailored for the sacred purpose of the buildings and the evolving needs of individual worshipping communities. A balance constantly needs to be struck which respects the rigour required of both ecclesiastical and secular authorities (with their competing but complementary demands), but is not so cumbersome that it deters and frustrates parishes and other interested persons and bodies from engaging with it.

The Faculty Jurisdiction Rules $2013^{2}$ are not rarefied legislation merely of interest to ecclesiastical lawyers: on the contrary, every parish priest, churchwarden and inspecting architect needs to be aware of these far-reaching revisions, as should diocesan staff and the members of diocesan advisory committees (DACs) and their secretariats also be. ${ }^{3}$ This brief 
Comment is designed to give a general overview of the scope of the altered landscape and to consider the impact of some of the more significant changes. ${ }^{4}$ It is no substitute for a thorough reading of the new Rules themselves and the accompanying Explanatory Memorandum. ${ }^{5}$

\section{THE FRAMEWORK}

The Faculty Jurisdiction Rules 2013 received the necessary approval of General Synod and Parliament and came into force on 1 January 2014. They apply in respect of all petitions submitted after that date. ${ }^{6}$ They take the form of an entirely fresh and holistic scheme, such that even those provisions which are familiar have been re-ordered and renumbered. The Rules replace three major statutory instruments: the Faculty Jurisdiction Rules 2000, the Faculty Jurisdiction (Care of Places of Worship) Rules 2000 and the Faculty Jurisdiction (Injunctions and Restoration Orders) Rules 1992, all of which are revoked. However, the content of much of these repealed provisions lives on in the new Rules, which comprise a single composite procedural code for the exercise of the faculty jurisdiction. They also include express provision for certain matters not previously addressed, such as interim faculties ${ }^{7}$ and costs. $^{8}$ In terms of structure, they are not dissimilar to the Civil Procedure Rules 1998, with which practitioners will be familiar, and begin with a statement of overriding objective and powers of case management before moving to specific procedural matters. They are subdivided into themed parts covering discrete topics and should prove more easily navigable than the dispersed provisions of the past.

\section{PRE-COMMENCEMENT CONSULTATION}

In terms of what must be done prior to the lodging of a petition for a faculty, the changes are of detail and not of substance. Part 3 provides that the advice of the DAC must first be sought and consultation is still required in specified circumstances with English Heritage and one or more of the national amenity societies. However, intending petitioners ${ }^{9}$ are now required to provide the DAC with a new 'standard information form' ${ }^{10}$ The burden of completing this form is ameliorated by the fact that it is also deployed at later stages in the process $^{11}$ and, since the information is largely generic for each church, may be retained and used repeatedly with successive proposals.

The requirements concerning the format and content of 'statements of significance' and 'statements of needs' have been revised in line with the judgment of the Court of Arches in Re St Alkmund, Duffield, ${ }^{12}$ particularly as it relates to the court's approach to proposed alterations to listed buildings. The 'statement of needs' must set out the justification for the proposals in question and, if they are likely to harm the architectural or historic significance of a church or other building, it must set out the basis on which it is said that the proposals would result in public benefit that outweighs the harm. ${ }^{13}$

The circumstances where intending petitioners are expected to consult English Heritage, any relevant national amenity society or the local planning authority are set out in Schedule 1 to the Rules. ${ }^{14}$ So far as possible, parishes are expected to carry out this consultation before seeking the formal advice of the DAC under Rule 3.1 and should provide the DAC with copies of any responses received from the bodies consulted. ${ }^{15}$ The 'penalty' for intending 
petitioners who choose not to consult at this stage is that there is likely to be delay later in the process, either when consultation is recommended by the $\mathrm{DAC}^{16}$ or if special notice is ordered by the chancellor. ${ }^{17}$

No longer will a DAC issue certificates. Instead the more apt term 'notification of advice' ${ }^{18}$ is given to the document by which the DAC communicates its expert assessment of any proposal. This 'notification of advice' is required to be in Form 2, which has been adapted to take account of the provisions of Rule 3.6. The options available to the DAC in giving its advice are unchanged: recommend; not recommend; or not object. However, under Rule 3.6(5), where the DAC's advice is that it does not object, a new provision introduced by the Rules states that the DAC 'must consider whether to include its principal reasons for giving that advice'. ${ }^{19}$ A statement that the DAC does not object is not always easy for intending petitioners or the court to interpret: hence the requirement to consider providing elucidation, although it is not mandatory that reasons are given.

As before, when giving its advice the DAC may make recommendations as to consultation with English Heritage, the local planning authority, relevant national amenity societies, the Church Buildings Council and others:

1. The DAC must make a recommendation that intending petitioners consult English Heritage, the local planning authority and relevant national amenity societies where such consultation is required under Schedule 1 and the relevant consultation has not already taken place. ${ }^{20}$

2. It must include a recommendation that intending petitioners consult the Church Buildings Council where proposals fall within Rule 8.6 (articles of special historic, architectural, archaeological or artistic interest) and where the Council has not already been consulted. ${ }^{21}$

Where the proposals involve seeking an injunction or restoration order, a 'notification of advice' in Form 2 is not appropriate and the DAC's advice is therefore required to take the form of a report or letter. ${ }^{22}$

A 'notification of advice' is valid for 24 months under the new Rules, whereas formerly it was 12 months. If the DAC confirms in writing to the chancellor that it does not wish to alter advice given within the previous 24 months, that will satisfy the statutory requirement for the chancellor to seek the advice of the DAC. ${ }^{23}$

\section{PROCEDURE}

Part 2 comprises provisions dealing with the application of the Rules and the interpretation of particular words and phrases. It adopts similar provisions to those in the Civil Procedure Rules for the calculation of periods of time when specified by the court for compliance purposes. 


\section{Parties}

Part 4 identifies the parties to faculty proceedings as petitioners, parties opponent and persons added as parties by the court by way of special citation. The term 'objector' is obsolete, although it might retain currency in respect of those who write letters of objection following public notice but decline to serve particulars of objection which would make them parties opponent. ${ }^{24}$ The details of the information to be sent to writers of letter of objection have been changed somewhat, to avoid discouraging such people from becoming parties to proceedings. The registrar's notice must explain that an objector who does not become a party opponent is not entitled to take part in the proceedings or to appeal. It must also contain a summary of the principles which apply in relation to costs in the consistory court. $^{25}$

\section{Form of petition}

The Petition itself, with which most parishes will be familiar, has been substantially shortened and simplified. ${ }^{26}$ Other forms have also been made more straightforward. In cases of exhumation, reservation of a grave space, or in relation to a memorial, Form $3 \mathrm{~A}$ is not to be used: instead the petition must be in a form approved by the chancellor under Rule 19.6(2). ${ }^{27}$

\section{Public notice}

The provisions on public notice are contained in Part 5 and broadly replicate the previous requirements. There is a power to dispense with public notice in cases of emergency ${ }^{28}$ and, for the avoidance of doubt, it is now made clear that the requirement of public notice is without prejudice to the power of the court to grant an interim faculty, for which provision is made in Part $14 .{ }^{29}$

\section{Special notice}

Part 8 restates the former provision relating to the giving of special notice of faculty petitions to certain bodies. There is a general discretion for a chancellor to direct publication in a newspaper, or other publication including a website. ${ }^{30} \mathrm{~A}$ new provision requires the chancellor to direct publication on the diocesan website of certain petitions by reference to the particular nature of the proposals. ${ }^{31}$ The requirements for consultation with English Heritage, national amenity societies and the Church Buildings Council are set out with greater clarity. ${ }^{32}$

\section{Service of documents}

Part 16 updates the existing provisions in the Rules concerning the service of documents. Under Part 16 there is wide scope for the use of electronic means of submitting documents to the registry, with the expectation that petitions can be submitted on-line and correspondence undertaken by email. 


\section{THE CONSISTORY COURT}

Except where the Rules specifically provide otherwise, the jurisdiction of the court is exercised by the chancellor, ${ }^{33}$ who must normally have advice from the DAC before determining a petition for a faculty or an application for an injunction or restoration order. ${ }^{34}$ Part 7 governs the exercise of the archdeacon's jurisdiction to grant faculties and differs from before in presentation only. Schedule 2 specifies the categories of works and other proposals which come within the archdeacon's jurisdiction. Rule 7.15 contains a new provision which requires an archdeacon to make specific enquiry of a parish at the expiry of a licence for temporary minor re-ordering to establish whether a faculty has been applied for and, if not, whether the position has been restored to how it was before. ${ }^{35}$

\section{Overriding objective and case management}

The functioning of the consistory court is now subject to the overriding objective that requires cases to be dealt with justly and expeditiously; ${ }^{36}$ and a clear and specific duty is imposed on the parties to help the court further the overriding objective. ${ }^{37}$ It is to be hoped that reference to the concept of fairness is no more than codification of a principle which has animated the court's conduct for centuries, but the requirement to deal with a case 'expeditiously' and 'in ways that are proportionate to the importance of the case and the complexity of the issues', together with 'saving expense', has a rather more contemporary tone. The court is required actively to manage the cases that come before it in a way that is intended to expedite the resolution of disputes and to avoid unnecessary delay. ${ }^{38}$ Case management includes encouraging the parties and other persons concerned in the petition to co-operate with each other in the conduct of the proceedings and in resolving matters that are in dispute between them. ${ }^{39}$ The provisions include identifying issues at an early stage, fixing timetables, dealing with the case without the parties needing to attend court and making effective use of technology. ${ }^{40}$ Expedition and the avoidance of delay is the abiding theme.

\section{Directions}

Part 10 makes provision for the court to give directions for the conduct of proceedings. When deciding what (if any) directions to give, the court must seek to give effect to the overriding objective. ${ }^{41}$ Rules 10.4 and 10.5 contain new material relating to witness statements and expert reports that reflects the equivalent provisions in the Civil Procedure Rules. Where the evidence of witnesses is to be presented at a hearing, the court must normally direct the service of witness statements setting out the evidence to be given by the witnesses in advance of the hearing. ${ }^{42}$ There is a mandatory requirement that oral evidence must be given under oath or solemn affirmation. ${ }^{43}$ Where expert reports are relied on they must comply with similar requirements to those in civil proceedings. ${ }^{44}$ Witness statements and expert reports are to stand as the evidence-in-chief of the maker unless the court directs otherwise. ${ }^{45}$ The national amenity societies are now afforded the same right as English Heritage to apply to give evidence. ${ }^{46}$ 


\section{Recording reasons}

Rule 6.3 introduces an entirely new obligation on the chancellor. Since it breaks new ground, rather than paraphrasing its provisions it is reproduced in full:

\section{Reasons for grant of faculty or dismissal of petition}

6.3-(1) Where an unopposed petition gives rise to a question of law or of doctrine, ritual or ceremonial or relates to proposals that affect the legal rights of any person or body, and the chancellor decrees the grant of a faculty but does not give judgment in court or hand down a written judgment, the chancellor must record in summary form the reasons for granting the faculty.

(2) Where a faculty is granted in opposed proceedings or where in any proceedings a petition is dismissed (in whole or in part) the chancellor must give a judgment in court or hand down a written judgment which contains the reasons for the grant or dismissal.

The requirement to give a judgment in opposed proceedings, or when dismissing a petition, is unsurprising. The Case Notes section of this Journal and the repository of judgments at the Middle Temple Library are testament to the increasing number of decisions emanating from consistory courts in recent years. The requirement to record summary reasons for granting a faculty in certain classes of unopposed petitions may take a little time to bed down. Broadly read, the determination of even the most uncontroversial petition is a question of mixed law and fact, doctrine permeates the most everyday business of the court, and people's legal rights are potentially engaged with relative ease. However, this provision is clearly intended to be read more restrictively, ${ }^{47}$ being a sensible requirement for the chancellor briefly to record the matters he or she considered and why they militated in favour of the grant of a faculty. It is not specified in the Rules where and in what form the reasons should be recorded nor whether such records should be open for public inspection. $^{48}$

\section{Interim faculties}

Part 14 deals with interim faculties, and provides a clear structure for a process which was becoming increasingly common, namely the grant of limited permission to proceed in cases of urgency or otherwise prior to the determination of a petition for a faculty. The previous rules (while acknowledging their existence) did not deal with interim faculties. The Rules deliberately leave the manner in which applications for interim faculties may be made to the discretion of the court, ${ }^{49}$ in consequence of their urgency; this is often done by telephone or email. Often, as in the case of lead theft, storm damage or arson, an interim faculty will be issued to maintain the status quo while a petition for a faculty is submitted and determined by the court following public notice and with the benefit of advice from the DAC and others. Rule 14.3 sets out certain terms which may or must be attached to the grant of an interim faculty. 


\section{INJUNCTIONS AND RESTORATION ORDERS}

The provisions previously contained in the Faculty Jurisdiction (Injunctions and Restoration Orders) Rules 1992 are conveniently set out, with minor revisions, in Part 15, which prescribes the procedure for applying for injunctions and restoration orders. It also states the circumstances in which the court may make such orders of its own initiative. Rule 15.10 is an entirely new provision which allows the court to accept an undertaking to do or not to do a specified act from a person against whom an injunction or restoration order is to be sought. ${ }^{50}$ The court has a discretion whether to accept an undertaking from the person concerned. A breach of an undertaking given to the court is punishable as a contempt of court, as would be a breach of an injunction or a restoration order. ${ }^{51}$

\section{COSTS}

While the powers of consistory courts to order costs were put on a statutory footing in 1963, previous rules have been silent on the matter of costs. ${ }^{52}$ Part 18 now provides that the court may exercise its power to make an order for costs at any stage in proceedings. Special provision is made for joining persons as parties to proceedings if the court is considering making an order for costs against non-parties. ${ }^{53}$ If the court proposes to make an order for costs other than at a hearing it must afford the person against whom the order is proposed to be made an opportunity to make representations to the court. ${ }^{54}$ The court may make a provisional order as to costs which is to stand unless the person against whom it is made makes representations within a period of time specified in the order. Costs are assessed by the registrar, with a right of appeal to the chancellor. ${ }^{55}$

\section{SUMMARY}

Certain of the changes reflect and formalise the manner in which those chancellors who are well versed in the Civil Procedure Rules of the civil courts have been exercising the inherent jurisdiction of the court for some years. But the new Rules make explicit the extent of the powers of the court to deal expeditiously with faculty cases, and the unambiguous statement of the overriding objective should lead to a much swifter and more transparent determination of all petitions. Bringing the dispersed provisions into a single composite document makes the Rules more easily navigable by court users, and presenting them in a manner akin to a Code is to be welcomed. The procedure is indeed simplified and more fit for purpose in the twenty-first century of electronic communication and 'hands-on' case management. But as the Rule Committee itself acknowledges, this is but the first of several waves of reform. ${ }^{56}$ Further work is to be done, much of which requires primary legislation in the form of amendments to existing Measures. Work is in hand and readers of this Journal will doubtless be kept abreast of developments as they make their way through the legislative business of General Synod and the Ecclesiastical Committee of Parliament.

\section{Footnotes}

\footnotetext{
${ }^{1}$ For a detailed exposition of the operation of the faculty jurisdiction, prior to the introduction of the new Rules, see MHill, Ecclesiastical Law (third edition, Oxford, 2007), ch 7.
} 
${ }^{2}$ SI 2013/1916. Unless the context states otherwise, all references hereafter to specific Rules are to those of the Faculty Jurisdiction Rules 2013. They were produced by the Rule Committee established by section 25 of the Care of Churches and Ecclesiastical Jurisdiction Measure 1991. Certain of the revisions arise from a number of recommendations that were made in the report of the Faculty Simplification Group dated 3 September 2013 and subsequently endorsed by the Archbishops' Council. They are the first wave of an ongoing process of revision and simplification which will include amendments to primary legislation.

${ }^{3}$ The Chairman of the Rule Committee circulated a detailed briefing note to diocesan secretaries and DAC secretaries in September 2013 in readiness for the implementation of the changes.

${ }^{4}$ I am grateful to Charles George QC, Dean of the Arches, Charles Mynors, Chancellor of Worcester, and Alexander McGregor, now Chancellor of Oxford, for commenting on this article in draft. However, the opinions expressed are my own.

${ }^{5}$ The Rules are available to download at <http://www.legislation.gov.uk/uksi/2013/1916/contents/made>. The Explanatory Memorandum may be found at <http://www.churchofengland.org/media/1783212/gs\%201887x\%20-\%20explanatory\%20memorandum.pdf>, both accessed 12 October 2013.

${ }^{6}$ There are transitional provisions for petitions lodged prior to that date which are yet to be determined. The former rules will continue to apply unless the chancellor directs otherwise: Rule 20.3.

${ }^{7}$ Part 14.

${ }^{8}$ Part 18.

${ }^{9}$ Rule 3.6 refers to 'intending applicants', whereas both Rule 4.1 and Forms 3A and 3B identify the person seeking a faculty by the term 'petitioner'. Rule 4.1(3) expressly states 'A person who submits a petition is referred to as a petitioner'. Neither the Rules nor the accompanying Memorandum explain semantically or ontologically how an intending applicant evolves into a petitioner. The term 'applicant' is not defined in the interpretation section but is used in Part 15 for those seeking an injunction or restoration order, who will be comparatively few in number.

${ }^{10}$ Rule 3.2(1)(a); Form 1A (parish) or 1B (other place of worship).

${ }^{11}$ Such as when the petition is lodged: see Rule 4.6.

${ }^{12}$ Re St Alkmund, Duffield [2013] Fam 158; [2013] 2 WLR 854.

${ }^{13}$ See Rules 3.3(1)(b) and (2).

${ }^{14}$ The precise circumstances when consultation is required are a little convoluted and differ depending on the particular consultee body and the listing status of the church building. Certain of the criteria contain an element of subjectivity where the test '... to such an extent as would be likely to affect ...' involves a value judgment. This is discussed a little more fully below, where the DAC has a discretion to recommend consultation.

${ }^{15}$ Schedule 1, para 7. Although it is not a requirement under the Schedule, intending petitioners would be wise also to include a reasoned response to any objections or observations made by a consultee body.

${ }^{16}$ Rule 3.6(6), (7) and (8).

${ }^{17}$ Rule 8.3. 
${ }^{18}$ Rule 3.6(1). Apparently, in the past, some parishes had mistakenly proceeded on the basis that the DAC certificate constituted authority to proceed. This change of nomenclature should prevent any similar misunderstandings in the future.

${ }^{19}$ Rule 3.6(5). A DAC is still under an obligation to give its principal reasons when its advice is not to recommend works or proposals: Rule 3.6(4).

${ }^{20}$ Rule 3.6(7).

${ }^{21}$ Rule 3.6(8).

${ }^{22}$ Rule 3.6(9).

${ }^{23}$ Rule 6.2(2). The routine seeking of written confirmation in every case is a needless administrative burden, wasteful of the time and resources of DAC secretaries and registry clerks. However the Rule Committee was constrained by section 15(1) of the Care of Churches and Ecclesiastical Jurisdiction Measure 1991, which imposes on chancellors a statutory duty to seek the advice of the DAC, as opposed to relying on the certificate issued to intending petitioners. It is expected that this bureaucratic anomaly will be removed when the Measure is itself amended in a future series of reforms.

${ }^{24}$ See Rules 9.2-9.5.

${ }^{25}$ Rule 9.3. This must be in a form approved by the chancellor. Reference might be made to the 'Guidance on the award of costs in faculty proceedings in the consistory court', drafted by the Ecclesiastical Judges Association and reissued in January 2011. A copy may be found at <http://www.peterboroughdiocesanregistry.co.uk/ejacostsbooklet.pdf>, accessed 30 September 2013.

${ }^{26} \mathrm{All}$ the forms are set out in Schedule 3 to the Rules. The Petition for parochial faculties is Form $3 \mathrm{~A}$, while that for non-parochial buildings (within the list under the Care of Places of Worship Measure 1999) is Form 3B.

${ }^{27}$ Rule 4.3(3).

${ }^{28}$ Rule 5.7.

${ }^{29}$ Rule 5.8.

${ }^{30}$ Rule 8.2.

${ }^{31}$ Rule 8.9, Schedule 1. This replaces the requirement under the previous regime for certain proposals to be the subject of advertisement in a local newspaper.

${ }^{32}$ Rules $8.3,8.6$ and 8.7

${ }^{33}$ Rule 6.1.

${ }^{34}$ Rule 6.2. For comment on the newly styled 'notification of advice', see above.

${ }^{35}$ Rule 7.15: once a scheme of temporary re-ordering has ceased to be authorised, the archdeacon is now under a duty to take steps to ensure that the position is restored to that which existed before the scheme was implemented: Rule 7.15(3).

${ }^{36}$ Rule 1.1.

${ }^{37}$ Rule 1.3. 
${ }^{38}$ Rule 1.4. For example, provision for holding hearings and receiving evidence by telephone is now made in Rule 17.1(2)(e).

${ }^{39}$ Rule 1.4(2)(a). The use of mediation may have a place here: see the work of BIMA (Belief in Mediation and Arbitration), which serves to promote alternative dispute resolution in matters having a religious dimension. See <http://www.bimagroup.org/>, accessed 2 October 2013.

${ }^{40}$ The court's case management powers are helpful grouped together in Part 17.

${ }^{41}$ Rule 10.1(2).

${ }^{42}$ Rule 10.4. This reflects the judgment of the Court of Arches in Duffield (see note 12 above).

${ }^{43}$ Rule $11.2(a)$, save for very limited exceptions.

${ }^{44}$ Rule 10.5.

${ }^{45}$ Rule 11.2(2). This reflects the practice under the Civil Procedure Rules, which had become commonplace in consistory courts in recent years.

${ }^{46}$ Rule 12.4. Similar provisions continue, as before, in respect of the evidence of the Church Buildings Council.

${ }^{47}$ For example, 'Upon whom is the burden of proof?' is a question of law to which every petition gives rise, albeit one with an easy answer. This cannot have been within the intent of the drafters of the Rule.

${ }^{48} \mathrm{~A}$ short and legible note which can be annexed to the file is probably sufficient, so that the chancellor or his or her successor can be reminded of the basis for the issue of the faculty. The chancellor's note (but arguably not the entirety of the file) should be available to inspection on request.

${ }^{49}$ Rule 14.2(3).

${ }^{50}$ It would be sensible, as in civil cases, for penal notices to be attached to undertakings as well as substantive orders, and for these to be signed by the individuals concerned to indicate that they are aware of the potential consequences of any breach.

${ }^{51}$ Contempt of an ecclesiastical court is dealt with by the ecclesiastical judge providing the High Court with a certificate specifying the act or omission that is said to constitute the contempt. If, on inquiry, the contempt alleged is found proved, the matter is punishable by the High Court: see Hill, Ecclesiastical Law, para 7.76.

${ }^{52}$ The Ecclesiastical Judges Association has issued guidance on the subject, as noted above (note 25).

${ }^{53}$ Rule 18.4 .

${ }^{54}$ Rule 18.1(2).

${ }^{55}$ Rules 18.2 and 18.3

${ }^{56}$ One proposed reform is the creation of a generic List of Minor Works (prescribing the categories of work which may be undertaken without the need for a faculty), which will be of universal application throughout the Church of England, eliminating the differences which currently exist between one diocese and another. 